250 anos de Ludwig van Beethoven (1770-1827) 


\section{"O espírito de Mozart pelas mãos de Haydn": 250 anos de Ludwig van Beethoven} EDUARDO MONTEIRO ${ }^{I}$ e MÔNICA LUCAS II

\section{Introdução}

A PRODUÇÃO musical de Beethoven (1770-1827) é, sem dúvida, uma das grandes aquisições culturais da humanidade. Mesmo em vida, seu legado já era reconhecido por sua qualidade singular e, 250 anos após seu nascimento, ainda preserva a capacidade de nos surpreender.

Tendo vivido em um momento histórico peculiar, de grande efervescência política, desenvolvimento de novas ideias estéticas e filosóficas e transformações sociais, a figura de Beethoven enseja discussões que ultrapassam, em muito, o âmbito de sua música. Nos estudos já produzidos sobre o compositor, encontram-se reflexões sobre seus posicionamentos políticos, relações com os ideais napoleônicos, opiniões no domínio da estética e dos ideais filosóficos do romantismo, emancipação do artista dos moldes sociais de patronagem aristocrática, acompanhados da ideia de artista como gênio criativo. Um aspecto muito explorado é aquele que discute sua produção à luz de sua biografia, especialmente da progressiva surdez que o acometeu e que já era total quando compôs algumas de suas maiores obras. Esses elementos têm gerado muitas camadas de compreensão e de abordagem do seu legado, de cunho político, psicológico, social, entre muitas outras.

Em texto recente, Marc Evan Bonds (2020) observa que as ligações entre a música de Beethoven e sua biografia só se tornaram uma tendência historiográfica após sua morte, em 1827. Afirma que, no enorme volume de escritos publicados ainda durante a vida do compositor - que, em um extenso, embora incompleto compêndio moderno (Kunze, 1987), somam quase 700 páginas -, praticamente inexistem textos que considerem questões pessoais como dados relevantes para a discussão sobre essa música. O trabalho de Bonds evidencia que o imenso impacto causado pelas composições de Beethoven junto a ouvintes de sua própria época raramente foi compreendido por meio de circunstâncias externas às próprias obras, e que esse tipo de visão é fruto de um momento posterior.

Bonds esclarece, ainda, que a tendência para se entender a música como uma espécie de biografia sonora de seu autor iniciou-se na década de 1830 , justamente com Beethoven. Segundo esse pesquisador, esse tipo de aborda- 
gem tendeu a predominar na avaliação da produção de compositores em geral, tornando-se dominante na historiografia musical durante quase todo século que se seguiu, embora, desde a década de 1920, já se reconheça seus limites.

Apesar da relevância e do interesse dos estudos que se debruçam sobre aspectos extramusicais relacionados ao fascinante momento histórico e à vida do compositor, Bonds, em sua historiografia sobre a recepção beethoveniana, evidencia como, ao longo dos séculos XIX e XX, a atenção à biografia de Beethoven tendeu a suplantar o exame de sua música. No entanto, o pesquisador americano defende que a inquietação que ainda hoje move seus ouvintes provém, principalmente, das próprias questões compositivas.

O intuito deste artigo é assinalar alguns pontos, inclusive aspectos composicionais, que ajudem a compreender a dimensão gigantesca que Beethoven detém no âmbito da história da música ocidental. Abordaremos sua produção no contexto da música instrumental a partir do final do século XVIII.

\section{O decoro da música instrumental no fim do século XVIII}

Até a metade dos Setecentos, as discussões que se debruçavam sobre temas musicais davam pouca relevância à música instrumental. A assertiva contida na República platônica, infinitamente repetida nos textos sobre música escritos entre os séculos XVI e XVIII, de que o ritmo e a harmonia devem estar subordinados à palavra, estabelece que os aspectos instrumentais sejam dignos de atenção apenas enquanto possibilidades para amplificar e iluminar o sentido do texto. Sob esse prisma, a música que não utilizava a palavra era entendida como mera diversão, incapaz, no entanto, de gerar uma emoção profunda ou levar à edificação moral, finalidade última - como afirmava Platão - de qualquer arte.

Nesse contexto, os gêneros musicais mais merecedores de discussão eram a missa, no âmbito sacro, e a ópera, no contexto secular. Dentre esses, a ópera teve proeminência no século XVIII como expressão favorita de sociabilidade nas cortes absolutistas.

A ópera setecentista é um gênero predominantemente italiano, envolvendo belas linhas melódicas que expressem a habilidade vocal - o chamado belcanto - devidamente acompanhadas por instrumentos musicais. Esse estilo vocal italiano predominou de maneira praticamente hegemônica na Europa entre os séculos XVII e XVIII.

A partir da segunda metade do século XVIII, começou a se consolidar, no mundo germânico, um estilo instrumental, notadamente sinfônico, que estimulou um acalorado debate estético envolvendo as possibilidades expressivas dessa música que não é mais subordinada à palavra.

Os dois grandes gêneros musicais que protagonizaram essa discussão foram a ópera, herdeira de uma forte e bem-sucedida tradição vocal, e a sinfonia, emblema do gênero instrumental por excelência, e que simbolizava a música nova. Ambos dividiram a preferência do público e ocuparam espaços específicos. Os teatros de ópera, que abrigavam companhias profissionais desde o século 
XVII, passaram a conviver com salões aristocráticos e com os primeiros teatros destinados aos concertos de música instrumental, surgidos no fim do século XVIII.

Poucos compositores da época lograram sucesso nos dois âmbitos. Por um lado, aqueles que seguiram o modelo vocal italiano, como Antonio Salieri (1750-1825) e Niccolò Jommelli (1714-1774), privilegiaram a prática da melodia acompanhada, explorando as possibilidades do belcanto, em detrimento da riqueza da harmonia. Por outro lado, os compositores que preferiram o novo estilo instrumental - como Carl Philipp Emmanuel Bach (1714-1788) ou Joseph Haydn (1732-1809) - dedicaram-se à expansão das possiblidades da música sinfônica, explorando sua maior riqueza timbrística e harmônica, mas obtendo sucesso mais limitado na música vocal. Wolfgang Amadeus Mozart (1756-1791) é um caso excepcional de compositor que foi capaz de lograr sucesso nos dois gêneros, combinando grande invenção melódica e riqueza harmônica com uma destreza raramente encontrada em seus contemporâneos.

Nos debates estéticos que ocorreram desde o fim do século XVIII, a música de Beethoven foi tomada como exemplo dos novos ideais sinfônicos e modernos. Sua produção foi considerada modelar tanto nas contendas filosóficas quanto na prática musical. É uma opinião comumente aceita que Beethoven constitui-se num ponto de divisão entre a música dos séculos XVIII e XIX, entre os estilos musicais assim denominados "Clássico" e "Romântico". Autores como Ratner (1980) e Crocker (1986) observam que Beethoven se diferencia radicalmente de seus contemporâneos, ${ }^{1}$ de modo geral, mais voltados para o sentimentalismo e o virtuosismo técnico. Nesse sentido, desprendem-se do ancoramento na tradição representada por Haydn, que fundamenta a técnica compositiva de Beethoven. Essa percepção de continuidade já está presente na crítica da época: por exemplo, em 1810, o compositor e crítico musical Johann Friedrich Reichardt (1810, I, p.31-2) expressa-a com a seguinte metáfora: "[Mozart] construiu seu palácio sobre o fantástico e acolhedor pavilhão de Haydn. Beethoven, desde cedo, já se sentira em casa nesse palácio, e só lhe restou construir, para expressar sua própria natureza em suas próprias formas, torres arrojadas e orgulhosas, às quais não é possível acrescentar nada sem quebrar o pescoço". ${ }^{2}$

A despeito da importância da produção sinfônica de Beethoven nesses debates estéticos, a enorme contribuição de sua obra não se restringe apenas ao gênero público da música orquestral. Sua presença nos rumos da música ocidental se dá em todos os âmbitos, e na maneira como amplia os procedimentos composicionais estabelecidos por Haydn e Mozart.

No entendimento do século XVIII, as circunstâncias em que se esperava ouvir música eram o teatro, a igreja e a câmera. ${ }^{3}$ Essas situações eram determinantes para definir o estilo de composição a ser utilizado. Sendo assim, na igreja, que simboliza a ocasião religiosa, esperava-se ouvir peças compostas segundo a técnica do contraponto, que se refere a uma textura composta por linhas me- 
lódicas independentes, porém simultâneas, muitas vezes imitando-se umas às outras. Esse estilo tradicional de composição, praticado a partir do século XII, foi denominado, no século XVIII, estrito ou antigo. No extremo oposto situava-se o teatro, que se materializava na ópera. O estilo prescrito para esta ocasião era totalmente diverso: para a ópera, pressupunha-se o uso de melodias vocais que exigiam habilidades técnicas e expressivas sofisticadas, apoiadas por um conjunto instrumental (normalmente com dois ou mais integrantes) que realizava um acompanhamento constituído de acordes, produzidos por um instrumento harmônico (em geral o cravo) e um instrumento melódico grave (a viola da gamba ou o violoncelo, por exemplo). O estilo que utiliza este tipo de acompanhamento, conhecido como "baixo-contínuo", surgido no início do século XVII, é descrito, em tratados setecentistas, como livre ou moderno. Neles, lê-se, ainda, que a câmera constituía-se no meio-termo entre o teatro e a igreja. Nesse espaço, que abrigava atividades voltadas para a diversão galante, como a conversação, a poesia e a música, essa posição intermédia previa uma escrita musical que consistia em uma mistura engenhosa entre as duas técnicas opostas de composição - o contraponto, ou estilo antigo, e a melodia acompanhada, ou estilo moderno. Esse espaço era entendido, no século XVIII, como o lugar, por excelência, da música instrumental.

O gênero de escrita musical considerado mais elevado na música instrumental Setecentista era a sonata. O termo, surgido no início do século XVII na Itália, designava uma peça tocada, em oposição à cantata, que indicava música vocal. Nesse contexto, sonata referia-se a peças destinadas ao decoro "de câmera". Em seu verbete "Sonata", na Allgemeine Theorie der schönen Kunste ["Teoria geral das belas-artes"], Johann Abraham Peter Schulz (1774, v.4, p.424-5) afirma: "Em nenhuma outra forma, além da sonata, a música instrumental tem possibilidade mais cômoda de mostrar a sua capacidade de descrever sentimentos sem palavras" (trad. Mário Videira). ${ }^{4}$

A sonata, segundo se lê nesses escritos, compreendia várias subespécies, designadas de acordo com o número de intérpretes: as peças para solista ou duo eram nomeadas "sonata", propriamente dita, ao passo que as formações com mais instrumentistas eram descritas de acordo com o número de intérpretes: trio, quarteto, quinteto etc. Quando, na sonata, as vozes eram dobradas por mais de um intérprete, a mesma recebia a denominação sinfonia.

Enquanto a sonata constitui-se num gênero musical, concerto, em sua origem, referia-se, antes, a uma peça escrita com contraste de timbres. ${ }^{5}$ Como adjetivo, o termo era aplicável a qualquer gênero musical, entre eles a sonata. A sonata concertata era, portanto, uma peça instrumental que reunia instrumentos contrastantes. No século XVIII, a sonata que contrastava um instrumento solo ou um grupo de instrumentos específicos com a orquestra passou a ser denominada concerto.

Apesar das semelhanças, pelo fato de serem ambos gêneros instrumentais, a sonata lançava luz sobre a habilidade do compositor e sua capacidade para 
representar as paixões da alma. O concerto, de modo diverso, constituía-se no lugar mais adequado à exibição da destreza técnica dos intérpretes.

Escritos setecentistas divergem, ao discutir se o concerto também devia ambicionar à representação das paixões, assim como a sonata (opinião de Heinrich Christoph Koch, 2001), ou se devia visar principalmente à exibição da destreza técnica, posição adotada por Johann Abraham Peter Schulz. ${ }^{6}$ No entanto, a desconfiança em relação ao maravilhamento provocado pelo virtuosismo levou autores do século XVIII, em sua maioria, a considerarem a sonata como o gênero mais elevado de música instrumental.

As sonatas, enquanto gênero, guardavam entre si aspectos identitários, como a divisão em 3 ou 4 movimentos, sendo o primeiro rápido e engenhoso, um movimento lento, um par de minuetos ou scherzi (às vezes ausentes) e um movimento final constituído geralmente por um rondeau.

No início do século XIX, as diversas formas de sonata continuaram a ser compreendidas como música "de câmara", ao passo que a sinfonia passou a constituir-se num âmbito próprio e distinto, o da música destinada aos recém-criados teatros públicos. As circunstâncias de recepção, tais como a qualidade dos intérpretes, o número e o conhecimento do público e as dimensões dos espaços, eram decisivos para o tipo de escrita musical empregada pelo compositor. A sonata (assim como trio, quarteto, quinteto) podia fazer uso de uma linguagem mais complexa, pois era destinada à audiência das câmaras, mais restrita e engenhosa, enquanto a sinfonia, que propunha atingir um público mais numeroso, o dos teatros, precisava fazer uso de uma linguagem mais grandiosa.

O surgimento dos concertos públicos, no fim do século XVIII, atesta o ganho de importância da música instrumental. Beethoven vivenciou diretamente esta mudança de status, e sua atuação teve um papel importante nessa alteração.

\section{As sonatas para piano}

As sonatas dedicadas a instrumentos de teclado solo foram estabelecidas em meados do século XVIII pelos compositores italianos Domenico Scarlatti (1685-1757), Baldassare Galuppi (1706-1785) e Domenico Alberti (17101740). Sua escrita remete ao estilo moderno, reforçado por um crescente virtuosismo.

Haydn foi o responsável por transformar o novo gênero. Constituiu-se num planejamento tonal mais variado, com harmonias bem delineadas, preenchidas por figurações idiomáticas, e abandonou a unidade de afeto, típica daquelas obras, em favor de uma nova sensibilidade dramática que privilegiava a variedade de sentimentos.

Beethoven não tardou a se apropriar do gênero, conferindo-lhe nova dimensão: acentuou o contraste entre os temas, dando amplitude inusitada à expressão, incorporou um virtuosismo inédito, baseado, provavelmente, em uma habilidade motora natural, e combinou sua genial inventividade como improvisador com o senso de construção e arquitetura musical herdado de seus mestres. 
Quando Beethoven mudou-se definitivamente de Bonn para Viena, em 1792, foi justamente seu virtuosismo ao teclado e, sobretudo, sua inesgotável capacidade como improvisador que lhe renderam fama. Escreveu então numerosos conjuntos de variações para piano baseados em temas de compositores como Dittersdorf (1739-1799), Grétry, Mozart, Paisiello (1740-1816), Salieri e outros. A natureza dessas peças, próxima da improvisação, talvez possa explicar porque nunca lhes atribuiu números de opus, inaugurando o registro oficial de sua produção em 1795, com três trios para piano e cordas op. l. Em 1796, portanto aos 26 anos, publicou sua primeira coleção para piano solo, as três Sonatas op. 2, dedicadas a Haydn, que havia sido, esporadicamente, seu professor nos primeiros anos na metrópole.

Provavelmente, nenhum outro conjunto de obras para piano recebeu tanta atenção crítica e editorial quanto as 32 sonatas de Beethoven. Elas abrangem quase toda sua vida criativa, de 1793 a 1822, e refletem a evolução de seu estilo, talvez mais do que qualquer outro gênero.

Desde o início, esse foi o campo preferido para suas experimentações mais inovadoras. Já no op. 2 , o intérprete se depara com exigências técnicas superiores àquelas encontradas nas sonatas de Haydn ou Mozart.

Apesar de ter iniciado na vida pública como pianista e improvisador e do inegável impacto de suas apresentações, Beethoven nunca teve paciência para estudar, o que, por vezes, ficava evidente em suas performances. Ao chegar em Viena, costumava tocar obras suas e de outros; depois só suas; mas sempre preferiu improvisar. Lamentavelmente, seus problemas com a crescente surdez obrigaram-no a abandonar definitivamente as apresentações em 1815.

É importante lembrar que a sonata pertencia, no século XVIII, à circunstância "de câmera", pois os recitais de piano, tal como compreendemos hoje, ainda não existiam. Concertos públicos eram esporádicos em Viena, e raramente incluíam uma obra para piano solo. O principal contexto para as apresentações pianísticas eram as reuniões privadas em salões aristocráticos ou burgueses, para um pequeno grupo de amigos, onde se praticava a chamada Hausmusik - música doméstica - ou os saraus semiprivados em palácios da nobreza. Embora a maioria dessas performances não tenha deixado rastros, há registros de que, na década de 1790, Beethoven tocou as três Sonatas op. 2 no palácio do príncipe Lichnowsky (1761-1814), na presença de Haydn. Carl Czerny (1791-1857) afirma que, nesses salões, o compositor tocava frequentemente o movimento lento da Sonata op. 28 e o Andante favori WoO $57 ; 7$ também o ouviu nas duas Sonatas op. $14 \mathrm{em} 1801$ ou 1802 (Cooper, 2017, p.10). Na esfera dos concertos públicos, sabe-se, por exemplo, que tocou dois movimentos da Sonata op. 2 n. 2 em Praga e uma "Grande Sonata", provavelmente a op. 22, em Viena (Cooper, 2017 , p.10). Essas apresentações, no entanto, fossem de Beethoven ou de outros pianistas, constituíram-se numa exceção. 
Quando Liszt, na década de 1840, criou o Recital de piano, que logo se popularizou, a adequação das sonatas de Beethoven ao contexto desses concertos públicos foi rápida e essas obras se tornaram a base do repertório, posição que ocupam até hoje.

Apesar de essas peças terem sido destinadas a ambientes privados e de muitas delas terem sido compostas para patronos que, normalmente, possuíam seu uso exclusivo por seis meses ou mais (Cooper, 2017, p.9), Beethoven nunca poupou esforços em seu processo criativo. Embora seja comumente identificado como a manifestação mais elevada do que se chama de gênio, sua atividade diária testemunhava uma enorme capacidade de trabalho e uma persistência incomensurável no refinamento de suas ideias. Prova disso são as mais de dez mil folhas de rascunhos que ainda sobrevivem. Nelas, algumas vezes, é possível identificar a origem de uma ideia musical e acompanhar sua evolução, que pode durar anos, até sua forma final. Dessa maneira, além da agudeza, ou a capacidade de conceber temas e reconhecer suas potencialidades expressivas, fica claro que as obras de Beethoven sofriam uma minuciosa elaboração técnica, que era tão importante, ou mais, do que a inspiração.

A busca por uma expressão original em suas obras pianísticas caminha em paralelo com a descoberta de novos recursos em um instrumento que se transformou, rapidamente, na mesma época. O fortepiano, como se denomina o instrumento histórico, antecessor do piano moderno, foi inventado por volta de 1711. Depois de uma evolução inicial relativamente lenta, tornou-se, no último quarto do século XVIII, o instrumento de teclado preferido, em substituição ao cravo. As ideias pianísticas de Beethoven sempre estiveram ligadas ao novo instrumento, mas, invariavelmente, estavam à frente das possibilidades dos fortepianos que possuiu. Suas demandas aos fabricantes foram um grande estímulo aos aperfeiçoamentos protagonizados pelos diferentes construtores.

Beethoven não se limitou a solicitar dos intérpretes de sua época a execução de movimentos rotineiros; propôs novas maneiras de tratar o teclado e de extrair dele sons até então desconhecidos. A capacidade de variações timbrísticas e de dinâmica do fortepiano levaram Beethoven a dotar suas obras de uma sonoridade sinfônica, completamente nova.

As mudanças no estilo musical que levam ao romantismo de autores como Chopin, Schumann e Liszt, no século XIX, estão diretamente relacionadas às novas possibilidades técnicas do instrumento e à consequente evolução da própria escrita pianística, protagonista e elemento incontornável para a compreensão desse processo como um todo.

Durante o que se considera seu primeiro período composicional, Beethoven se dedicou com especial afinco à sonata para piano, o que se reflete em um elevado número de obras. De 1793 até o fim de 1802, ano geralmente considerado o início do seu segundo período, Beethoven compôs vinte sonatas. É surpreendente que, nos 25 anos que lhe restam de vida, tenha composto apenas 
outras 12. A partir dessa ocasião, passa a expressar reservas a respeito desse tipo de produção. Em 23 de novembro de 1802, em resposta a um pedido de um editor para compor três sonatas, Kaspar Anton Carl, irmão de Beethoven, escreve em seu nome: "Se você quiser três sonatas para piano... não poderá recebê-las simultaneamente, mas uma a cada cinco ou seis semanas, porque meu irmão não se preocupa mais com essas ninharias e escreve apenas oratórios, óperas etc." (apud Cooper, 2017, p.3).

Atitude semelhante se verifica em uma carta de 1809 para a editora Breitkopf \& Härtel: "Não estou interessado em escrever sonatas para piano solo, mas prometo-lhe algumas" (apud Cooper, 2017, p.4). Em 1818, queixa-se de ter que escrever para assegurar o "pão de cada dia", mas reconhece que é isso o que lhe permite se dedicar a uma "grande obra"; e no ano seguinte declara: "É difícil compor quase somente para ganhar o pão" (apud Cooper, 2017, p.4). Em ambas as ocasiões, a obra em questão não era outra, senão a Sonata $o p .106$, "Hammerklavier". O mesmo tipo de reclamação ocorre em relação às Sonatas op. 110 e 111, cuja composição comprometia seu trabalho na Missa Solemnis. Independentemente de seu humor a respeito dessas obras "ganha-pão", Beethoven nunca abandonou os mais altos padrões e essas sonatas tardias estão entre suas obras-primas.

Entre 1803 e 1805, Beethoven compôs duas obras impressionantes: as Sonatas op. 53 ("Waldstein") e op. 57 ("Appassionata"). Elas exploram o potencial técnico e virtuosístico do fortepiano de forma inovadora: arpejos cobrindo todo o teclado, passagens velocíssimas (inclusive em oitavas), notas repetidas, cruzamento de mãos, grandes saltos, sucessões de acordes, uso revolucionário dos pedais e dos trinados, efeitos sonoros inusitados, timbres surpreendentes e sonoridade orquestral. Além disso, verifica-se uma grande diversidade de climas e uma densidade expressiva única. Essas peças elevaram o gênero a um patamar até então incomparável e alteraram profundamente as expectativas que se tinham sobre a sonata para piano. Sua importância, possivelmente, só será igualada pelas cinco obras compostas em sua última fase: as Sonatas op. 101, 106, 109, 110 e 111 , escritas entre 1816 e 1822.

A composição dessas duas obras-primas, que podem ter preenchido suas ambições e expectativas no âmbito pianístico, somada à estreia da Terceira Sinfonia, "Eroica" (em 1803), cujas inovações inauguravam uma nova fase de sua produção orquestral, com perspectivas estimulantes para um jovem compositor de 35 anos, podem, talvez, explicar o aparente desinteresse de Beethoven em escrever para piano solo a partir dessa época.

Muitas dessas sonatas, entre elas as duas mencionadas acima, possuem epítetos. Alguns deles foram acrescentados nas partituras impressas pelos editores - possivelmente com a ciência do compositor - e outros foram atribuídos postumamente, devido ao forte poder de sugestão e comunicação dessas obras. A Sonata "Patética" (op. 13) é um exemplo do primeiro tipo. O editor gravou, em 
francês, Grande Sonate pathétique, provavelmente impressionado com o caráter trágico da introdução. No caso da "Appassionata" (op. 57) e da "Pastoral" (op. 28), os apelidos, que fazem referência ao clima das peças, também foram dados pelo editor, mas depois da morte do compositor.

No caso das duas Sonatas op. 27, os subtítulos quasi una fantasia são, provavelmente, de autoria de Beethoven. No entanto, a Sonata op. $27 \mathrm{n} .2$ ficou conhecida como "Sonata ao Luar", em virtude de um comentário do crítico e poeta alemão Ludwig Rellstab, em 1832, comparando seu primeiro movimento ao brilho do luar sobre o Lago de Lucerna. Apesar de esse título possuir defensores e detratores, é inegável que o movimento, ao manter, por cerca de cinco minutos, uma sonoridade extremamente suave em que as harmonias se misturam de forma livre e delicada, constitui-se numa das maiores ousadias de sua produção. ${ }^{8}$ Não há registro anterior de nada parecido na literatura pianística. No caso da "Tempestade" (op. 31 n.2), o nome advém de uma conversa em que Beethoven teria recomendado a leitura da Tempestade de Shakespeare, para auxiliar a compreensão da peça. No entanto, acredita-se hoje que a referência teria sido, na verdade, à publicação Betrachtungen über die Werke Gottes im Reiche der Natur ["Reflexões sobre as obras de Deus na natureza", 1772-1776], do pregador protestante Christoph Christian Sturm (1740-1786) que Beethoven possuía, ricamente anotada, em sua biblioteca. ${ }^{9}$

Alguns apelidos têm origem no nome do homenageado na dedicatória. É o caso das Sonatas "Waldstein" ( $o p .53$, dedicada ao conde Ferdinand Ernst Gabriel von Waldstein) e "à Thérèse" ( $o p .78$, dedicada à condessa Thérèse von Brunswick).

A Sonata "Les Adieux" (op. 81) é um dos raros casos em que há o registro da intenção do compositor em relação ao título. Ao receber a cópia da partitura impressa, Beethoven queixou-se, de forma veemente, que a edição incluía, além do título em alemão - Lebewohl, Abwesenheit und Wiedersehen ("Despedida, ausência e retorno") - a tradução francesa (Les Adieux, l'Absence et le Retour), argumentando que Les Adieux é uma expressão impessoal, que pode se destinar a um indivíduo ou a um grupo, ao passo que Lebewobl refere-se, de forma emotiva, a uma só pessoa. ${ }^{10} \mathrm{O}$ título alude à despedida do arquiduque Rudolph, seu mecenas, aluno e amigo pessoal, a quem a obra é dedicada, que deixara Viena, em face do ataque das tropas de Napoleão, em 1809.

O título "Hammerklavier" (op. 106) vem de um pedido de Beethoven ao editor para substituir, na partitura impressa, a palavra italiana "pianoforte" pela correspondente alemã. O curioso é que a demanda foi feita, e atendida, para as cinco últimas sonatas, desde a op. 101. No entanto, apenas a op. 106 é conhecida por esse epíteto. A solicitação do compositor teve como objetivo deixar claro que essas obras não poderiam ser tocadas em outros instrumentos de teclado, como o cravo ou o clavicórdio, devido à escrita idiomática para o piano, que ia muito além das possibilidades daqueles instrumentos. 
Suas cinco últimas sonatas, compostas entre 1816 e 1822, já antecipam traços da expressão e do pianismo que caracteriza compositores como Schumann e Liszt. Nesse sentido, representam um elo com o futuro. Pode-se dizer que tanto seus movimentos lentos quanto a variação 31 das Variações "Diabelli”, op. 120 - sua última grande obra para teclado e uma das maiores jamais escritas -, buscam e logram alcançar uma expressão que, de alguma forma, nos remete à ideia de transcendência, que é traduzida em palavras nos versos da ode $A n$ die Freude ["À Alegria”] de Friedrich Schiller (1759-1805), utilizados na Nona Sinfonia. O emprego de sonoridades etéreas nas regiões aguda e superaguda do teclado, muitas vezes com pedalização generosa, e escalas diáfanas ascendentes, que parecem se dirigir a um ansiado Paraíso, são alguns dos recursos utilizados para traduzir esse tipo de sentimento.

Frequentemente, essas obras finais não foram bem compreendidas por seus contemporâneos, que as consideraram complexas, herméticas ou mesmo fruto de uma personalidade excêntrica e decadente. De forma visionária, Beethoven escreveu, a respeito da Sonata op. 106, que ela manteria os pianistas ocupados quando fosse tocada... em 50 anos! (Solomon, 1987, p.399) - previsão certeira, já que, além de Liszt, Clara Schumann e Hans von Bülow, poucos pianistas do século XIX enfrentaram os imensos desafios técnicos e musicais dessa obra monumental.

\section{Música de câmera}

Vimos acima que, no século XVIII, as sonatas compostas para grupos a partir de três integrantes eram designadas segundo o número de participantes: trio, quarteto, quinteto etc. Os gêneros que envolvem mais de um instrumentista exploram, frequentemente, a combinação de timbres diversos e respondem ao desafio de conciliar a natureza distinta das emissões sonoras de sopros, cordas, teclados etc. ${ }^{11}$ Desde o início do século XIX, as sonatas para pequenos conjuntos, originalmente destinadas aos salões, passaram a ser denominadas, especificamente, como música "de câmera", excluindo, dessa forma, a sonata solo e a sinfonia.

Até a metade do século XVIII, a escrita de sonatas para diversos instrumentos pressupunha o acompanhamento do "baixo-contínuo", que evidenciava a condução da harmonia, geralmente por meio do cravo ou do órgão. No decorrer da segunda metade do Setecentos, a mudança estética que passou a privilegiar um ritmo harmônico mais lento e acordes mais claramente definidos tornou esta prática obsoleta. Nesse processo, o cravo foi aos poucos sendo substituído pelo fortepiano, cuja possibilidade de realizar dinâmicas gradativas, crescendo e decrescendo, ensejaram o desenvolvimento de uma escrita idiomática. O piano ganhou então protagonismo e os demais instrumentos (flauta, violino, violoncelo etc.) passaram, muitas vezes, apenas a dobrar as linhas do pianista, chegando a ser descritos como um acompanhamento opcional (ad libitum).

O período criativo de Beethoven coincidiu com uma época de grandes alterações na maioria dos instrumentos musicais, fato que teve impacto direto 
em sua escrita. No fortepiano, o teclado se expandiu (tanto para o grave quanto para o agudo) e uma estrutura mais robusta possibilitou maior volume sonoro e ressonância. Processos semelhantes ocorreram nos instrumentos de sopros e de cordas. Por exemplo, a invenção do arco côncavo, substituindo o modelo convexo, desenvolvido por François Tourte (1747-1835) na década de 1780, possibilitou aos instrumentos de cordas um aumento de potência e a possibilidade de realizar linhas melódicas mais longas e sustentadas.

Utilizando as inovações propostas por Tourte, o violinista Giovanni Battista Viotti (1755-1824) e o violoncelista Jean Louis Duport (1749-1819) foram os responsáveis por estabelecer, em Paris, as bases de uma técnica moderna para os seus respectivos instrumentos. Beethoven, que estudou violino e viola em Bonn, teve contato com Rodolphe Kreutzer (1766-1831), Pierre Rode (1774-1830) e Pierre Baillot (1771-1842), representantes mais jovens desta assim chamada escola violinística francesa e, em 1796, teve oportunidade de tocar com Duport, em Berlim.

É interessante notar que a escrita de Beethoven para o gênero camerístico, em um primeiro momento, se apropriou de modelos mozartianos: o Divertimento para trio de cordas K. 563, o Quinteto para piano e sopros K. 452 e o Quarteto de Cordas K. 464 de Mozart serviram, respectivamente, como base para o Trio de Cordas, op. 3, para o Quinteto op. 16 e para o Quarteto op. 18 n.5.

\section{Música de câmera com piano}

O fato de Beethoven, no início de sua carreira, ter se sobressaído como pianista no contexto das câmeras aristocráticas, assim como o sucesso dos mais de quarenta trios para piano, violino e violoncelo compostos por Haydn para estes ambientes talvez explique a opção de Beethoven por essa formação para sua primeira publicação (op. 1, 1794-1795).

Haydn adotara em seus trios uma escrita herdada da sonata para piano acompanhada por instrumentos opcionais. Neles, o violoncelo dobrava os baixos do pianista, executando a função de acompanhador a ele atribuída desde o surgimento do "baixo-contínuo". O violino, entretanto, recebia um tratamento mais independente, ora dobrando, ora dialogando com o piano. Beethoven, desde seus primeiros trios (op. 1), propõe maior equilíbrio na distribuição temática entre os instrumentos, o que resulta em uma valorização do papel das cordas, perceptível, por exemplo, no destaque dado a elas na seção central do Adagio do Primeiro Trio.

O Trio op. 1 n. 3 protagonizou a deterioração definitiva do relacionamento entre Haydn e Beethoven. Aparentemente mais preocupado com a recepção do Trio do que com aspectos técnicos da obra, Haydn expressou reservas sobre essa peça, o que teria ofendido Beethoven permanentemente.

Em 1796, durante sua visita a Berlim, Beethoven escreveu duas sonatas para violoncelo (op. 5). A destinação a Jean Louis Duport, músico de altíssi- 
mo gabarito, certamente explica o grau de dificuldade técnica da escrita para esse instrumento nessas peças, muito superior ao das anteriores. Surpreendentemente, esses são os primeiros exemplos na história da música de sonatas para violoncelo com partes de piano totalmente escritas e não mais cifradas. Nelas, o violoncelo é tratado de maneira completamente nova, com linhas melódicas independentes do piano. Como nem Haydn nem Mozart produziram sonatas para este instrumento, estas obras tiveram importância fundamental na definição do gênero e de suas possibilidades.

De 1798 a 1803, Beethoven compôs nove sonatas para violino e piano. A escrita das partes violinísticas, sobretudo da nona, op. 47 ("Kreutzer"), é tão idiomática e virtuosística quanto qualquer grande obra posterior desse repertório. Na introdução ao primeiro movimento, um Adagio sostenuto, Beethoven divide o material temático de maneira equânime entre os dois instrumentos. Tal preocupação não se encontra na música de Haydn e Mozart. Ao se avaliar o total da produção camerística de Beethoven, percebe-se uma busca pelo equilíbrio da importância de todos os participantes. Esse tipo de escrita passou a ser um padrão adotado pelos compositores que se dedicaram ao gênero a partir do século XIX. Nesse sentido, a Sonata "Kreutzer" constitui-se num divisor de águas, comparável ao papel desempenhado pela Terceira Sinfonia, "Eroica" (op. 55), no âmbito sinfônico. Curiosamente, as duas peças foram compostas no mesmo ano, 1803.

A produção camerística de Beethoven envolvendo o piano segue o mesmo padrão de suas sonatas solo para o instrumento: está concentrada principalmente no período entre 1792 e 1803 . Esse espaço de tempo comporta 20 de suas 29 peças no gênero.

As obras mais importantes que se seguiram foram a sonata para violoncelo op. 69 (1807), dois Trios op. 70 (sendo o primeiro conhecido como "Fantasma", 1808), a última sonata para violino e piano, op. 96 (1812), o Trio "Arquiduque", op. 97 (1810-11), e duas sonatas para violoncelo, op. 102 (1815). Entre essas, destaca-se o Trio "Arquiduque", obra em que Beethoven faz uso de uma sonoridade orquestral que claramente antecipa Brahms.

Em seus doze últimos anos de vida Beethoven abandonou totalmente a escrita de música de câmara com piano, concentrando-se nos quartetos de cordas. Esse fato talvez explique o relativo pouco interesse por aquela produção no contexto dos estudos sobre o compositor.

\section{Quartetos de cordas}

Os estudiosos são unânimes em situar o conjunto constituído pelos seus 17 quartetos de cordas como o ponto mais elevado da música de Beethoven.

O quarteto de cordas representou um grande desafio para compositores da geração posterior à de Haydn e Mozart. No fim da década de 1790, quando Beethoven se aproximou pela primeira vez da ideia de compor quartetos, as obras desses dois mestres já eram consideradas modelares. Haydn escrevia quartetos 
de excelente qualidade havia vinte anos, e, naquela mesma década, produziu outros quatorze, três dos quais dedicados ao príncipe Lobkowitz (1772-1816), o mesmo que encomendaria a Beethoven seus primeiros seis Quartetos (op. 18).

Compreendendo a importância da encomenda e o peso da comparação, Beethoven trabalhou arduamente: constam, de sua pena, nos anos 1790, cópias de peças dos dois mestres. Sobrevive, ainda, uma versão provisória de um dos quartetos do op. 18, enviada ao violinista Karl Amenda, que estrearia a obra. Beethoven solicita que a peça seja avaliada, porém não divulgada, uma vez que ainda estava em processo de revisão. $\mathrm{Na}$ mesma carta, afirma ter, finalmente, aprendido a escrever quartetos. Entre o rascunho enviado a Amenda e a versão final constam, de fato, diversas alterações.

Nos quartetos de cordas, assim como em suas demais obras, Beethoven empregou estratégias composicionais herdadas de Haydn e também utilizadas por Mozart: motivos simples que se conformam em unidades temáticas que, expandidas, geram, por sua vez, seções amplas. Embora Beethoven preencha os moldes formais herdados de seus antecessores com materiais originais, seus quartetos não chegam a romper com as técnicas de composição setecentista; contudo, neles, os procedimentos são ampliados a limites inconcebíveis nas peças de seus antecessores. Os contrastes dinâmicos dão aos quartetos um colorido sinfônico. A gama de emoções representadas torna-se muito mais variada, e, com isso, a sutileza e a graça da escrita de Haydn dão lugar a expressões que podem ser violentas e até mesmo grosseiras.

Os quartetos de cordas, tal como haviam sido concebidos por Haydn, eram providos de uma escrita engenhosa, destinada, originalmente, a amadores competentes ou a profissionais que os executavam em ambientes íntimos, por puro deleite, ou para um grupo seleto de conhecedores, frequentadores dos salões aristocráticos, geralmente sem ensaios prévios. Os quartetos iniciais de Beethoven, op. 18 (1801), encaixam-se nessa concepção, embora mesmo estes já tenham sido considerados pela crítica da época como "difíceis e nada populares" (apud Kindermann, 2006, p.2).

O grupo de quartetos subsequentes, compostos entre 1809 e 1810 (op. 59 , op. 74 e op. 95), é ainda mais exigente. Somam-se, à complexidade das partes individuais, a necessidade de uma sincronia fina entre os instrumentos e uma capacidade de entoar harmonias incomuns. Essas dificuldades constituíram-se em obstáculos para sua interpretação por músicos amadores.

Em 1808 surge o primeiro quarteto profissional de atuação regular, o Quarteto Razumovsky, liderado pelo violinista Ignaz Schuppanzigh, que realizou a première dessas obras de Beethoven, a partir do op. 59. A escrita do compositor para esse gênero, a partir dessa época, reflete um intenso trabalho de colaboração com esse grande violinista. Além das dificuldades de interpretação, ouvintes da época também se referem a essas peças como "longas, complexas, profundas e excelentes, mas difíceis de se compreender" (apud Kindermann, 
2006, p.6). O próprio Beethoven admite, a respeito do Quarteto op. 95, que a peça "é escrita para um pequeno círculo de conhecedores e nunca deve ser executado em público" (apud Kindermann, 2006, p.6).

Os seis quartetos de cordas finais (op. 127, 130, 131, 132 e 135 e a Grande Fuga op. 133) foram compostos já em completa surdez, entre 1824 e 1826 e são suas últimas grandes obras terminadas. Nesses, as dificuldades técnicas, de entrosamento e de interpretação são ainda mais desafiadoras.

Em 1823, em uma iniciativa surpreendente, Schuppanzigh criou uma série pública de música "de câmera", na qual executou todos os quartetos finais de Beethoven. É curioso observar que peças de tal dificuldade constituíram-se nos primeiros quartetos de cordas apresentados em concertos públicos em Viena. Até então, nestes eventos, tocavam-se peças que, por definição, eram destinadas a plateias amplas, como o concerto e a sinfonia. Nos anos 1790, Haydn também escrevera quartetos de cordas para grandes plateias em Londres, porém, nessas peças, optara por uma escrita mais simples e clara. Beethoven caminha no sentido oposto: a dificuldade das obras é tal que seus quartetos passaram a ser publicados não apenas em partes separadas, para uso dos intérpretes, mas, também em partitura, reunindo os quatro instrumentos, de modo a auxiliar a escuta pelos ouvintes. Os próprios editores advertiam os compradores que se tratava de obras excessivamente difíceis para amadores. Schuppanzigh, após um concerto malsucedido, atribuiu seu fracasso à complexidade da música e à dificuldade da leitura resultante da originalidade da escrita.

Em sua época, os quartetos de cordas finais de Beethoven não deixaram de figurar no âmbito dos salões aristocráticos, e é significativo encontrar notícias de eventos em que as peças foram ouvidas duas vezes em seguida, na tentativa de viabilizar sua compreensão. A extensão, assim como a ausência de interrupção entre os movimentos, que não dava oportunidade para os músicos descansarem ou corrigirem a afinação, constituíram-se num desafio adicional para os ouvintes, desde os tempos de Beethoven até hoje. Na época, as peças foram consideradas, de forma geral, herméticas e de compreensão difićlima. A Allgemeine Musikzeitung zur beförderung der theoretischen und praktischen Tonkunst ["Jornal musical para o incentivo da teoria e prática"] publicou, em 1827:

Julgamentos sobre estas obras deste mestre são muito divergentes; de fato, muitas vezes completamente contraditórios. Alguns dizem não haver nada mais belo e maravilhoso que este Quarteto [op. 127], que representa o máximo que a música pode oferecer; outros dizem: 'não, tudo aqui é nebuloso, tudo é confuso; não há ideia clara desenvolvida, pois em cada compasso há pecados contra as regras aceitas. (apud Kindermann, 2006, p.7)

Essa percepção ambígua, que mistura grandiosidade e impenetrabilidade, não se alterou substancialmente nos dias de hoje. Os quartetos de cordas finais são considerados como algumas das maiores obras jamais compostas. Contudo, sua dificuldade continua a desafiar intérpretes e ouvintes. 


\section{Os concertos para piano}

Enquanto a música para piano solo e de câmera pertence ao universo restrito dos salões aristocráticos, o concerto e a sinfonia, sem abrir mão desse espaço, passaram a se destinar, no fim do século XVIII, também às apresentações públicas. Embora já houvesse temporadas importantes de concertos abertos em Londres, esses eventos ainda eram raros em Viena.

O compositor que aspirasse tornar sua música conhecida de uma audiência mais ampla do que aquela que frequentava os salões da nobreza, podia organizar o que se costumava chamar de "academia": um concerto aberto ao público pagante. O repertório das academias era variado, constituído por verdadeiras maratonas musicais com duração média de três horas em que se alternavam solistas, coro e orquestra.

Ao longo de sua carreira, Beethoven organizou onze academias para seu próprio benefício. Dada a importância das obras apresentadas, o evento ocorrido em 22 de dezembro de 1808 no Theater an der Wien merece destaque. Nessa noite foi possível ouvir as estreias das Quinta e Sexta Sinfonias, do Quarto Concerto para piano e da Fantasia Coral, além de uma ária, dois movimentos da Missa em dó maior e uma improvisação com Beethoven ao piano.

Em sua definição do termo "concerto", o dicionário musical de Koch (2001, col.349) deixa clara a importância de o solista demonstrar suas habilidades durante a execução dessas peças. Nessa época, comumente, era o próprio compositor que assumia esse papel. Essa foi a principal motivação para Mozart escrever seus 27 Concertos para piano e orquestra, que estão entre suas obras mais inspiradas e desempenharam papel fundamental na consolidação do gênero.

Entre 1790 e 1809 Beethoven escreveu sete concertos para os quais atribuiu número de opus: cinco para piano (op. 15, 19, 37, 58 e 73), um para violino (op. 61) e o Concerto Tríplice, para violino, violoncelo e piano (op. 56).

Para Beethoven, a importância dos concertos como oportunidade de demonstrar sua própria destreza como pianista fica evidente na relutância em publicar suas primeiras obras no gênero, manifesta em cartas de 1800 a Franz Anton Hofmeister: "no momento, continuo guardando os melhores [concertos] para mim, até que eu mesmo faça uma turnê" (apud Chiantore, 2010, p.66).

O Concerto n.1, op. 15, data de 1795 e, na realidade, foi o segundo a ser escrito. Sua primeira obra do tipo foi, de fato, o Concerto n.2 (op. 19), composto no início da década de 1790. A inversão da ordem de publicação se deve, provavelmente, às reservas que o compositor tinha em relação a este último, expressas em uma carta à editora Breitkopf \& Härtel de 1801 (Kindermann, 2000, p.107). Pode-se supor que havia ainda o receio da comparação inevitável com o grande legado de Mozart, do qual, na verdade, ambos os concertos são tributários, o que teria levado Beethoven a refazer inteiramente o último movimento do op. 19, cuja versão original foi publicada postumamente por Czerny como o Rondo $\mathrm{WoO} 6$. 
O Concerto n.3, op. 37, composto entre 1800 e 1803, e o Concerto Tríplice, op. 56, terminado em 1805, enquadram-se, por seu caráter heroico, no segundo período composicional de Beethoven e, apesar de já manifestarem sua personalidade madura, podem ser considerados como preparatórios para as três últimas e magistrais obras-primas do gênero. A estreia do Concerto n.3 se deu em 1803, com o autor ao piano. Quanto ao Concerto Tríplice, apesar de Haydn e Mozart terem escrito algumas obras para mais de um solista, a combinação escolhida por Beethoven - piano, violino e violoncelo - não tem precedentes na literatura.

Pode-se dizer que os Concertos para piano n.4, op. 58 (1806), e n.5, op. 73 (1809), assim como o Concerto para violino, op. 61 (1806), encerram a era dos concertos clássicos e inauguram uma nova, em que o objetivo principal, apesar de sua enorme dificuldade técnica, não é mais a exibição de virtuosismo do solista, mas expressar uma visão de conjunto que integra solista e orquestra. Esse novo estilo de concerto sinfônico vai repercutir fortemente em compositores como Schumann e Brahms.

O Concerto n.4, dedicado a um de seus importantes patronos, o príncipe Lobkowitz, é, sem dúvida, uma das maiores obras de Beethoven. Como várias outras composições desse período, exibe uma serenidade lírica e ampla. Esse concerto surpreende por seu início inesperado: ao invés de uma longa e imponente introdução orquestral, que fazia parte do protocolo do gênero, a obra principia com um breve solo de piano, que apresenta o tema principal de forma singela e delicada. Embora tal fato não cause mais espanto hoje, certamente a ousadia não passou despercebida pelo público da época.

O último Concerto para piano, n.5, "Imperador", op. 73, foi composto em 1809, durante o período em que Viena estava sob o domínio de Napoleão. Escrito em mi bemol maior, mesma tonalidade da Terceira Sinfonia, "Eroica", seus movimentos externos possuem um caráter majestoso, com figuras rítmicas que evocam o estilo militar. É possível que Beethoven acalentasse o desejo de estrear a obra como solista, anseio inviabilizado por sua condição auditiva. Isso talvez explique o lapso de tempo entre a conclusão da peça e suas premières. A estreia privada ocorreu em 13 de janeiro de 1811 no Palácio do príncipe Lobkowitz em Viena, com o arquiduque Rudolf (1788-1831), seu dedicatário, no papel de solista. O primeiro concerto público se deu em 28 de novembro de 1811 , na Gewandhaus de Leipzig, com o pianista Friedrich Schneider. Finalmente, em 12 de fevereiro de 1812, a obra teve sua estreia em Viena. Coube a Czerny a honra de executá-lo diante do mestre.

Provavelmente foi a impossibilidade de se apresentar como solista que levou Beethoven a desistir de compor concertos para piano e orquestra durante seus 18 anos finais.

\section{As sinfonias}

Ao discorrer sobre a obra de Beethoven, provavelmente o gênero musical que venha mais imediatamente à cabeça seja o sinfônico. Embora as contribui- 
ções de Haydn e Mozart nesse campo sejam excepcionais, o conjunto das nove sinfonias de Beethoven constitui-se num marco na história da música. Para avaliar a magnitude desse legado, é interessante partir das prescrições para o gênero estabelecidas no século XVIII.

Koch, em seu dicionário (1802), refere-se à sinfonia como um gênero instrumental, completo em si e independente, de caráter brilhante, grandioso e fogoso, relacionado à sonata, com partes dobradas por diversos instrumentos, que visa colocar o ouvinte em uma disposição de espírito elevada. Aponta ainda Haydn como seu mestre.

No âmbito da harmonia, explica que a sinfonia se caracteriza por um planejamento tonal bem configurado, com o emprego de harmonias claramente reconhecíveis e hierarquicamente organizadas (Koch, 2001, col.1386-1387). Essa prescrição tem como modelo a transparência e a direcionalidade harmônica perceptível nas sinfonias de Haydn e Mozart, que obtém estas qualidades mediante o uso de progressões de acordes mais lentas do que as dos compositores que lhe haviam precedido. Beethoven alarga ainda mais o passo das mudanças de harmonia, conferindo maior tensão a cada acorde. Nesse sentido, a impressão geral de grandeza e energia gerada por suas sinfonias não vêm tanto do uso de acordes mais complexos, mas sim de sua duração e, sobretudo, de seu emprego mais eficaz.

O prolongamento das harmonias associa-se ao uso de figurações idiomáticas preenchendo esses espaços, baseadas, por exemplo, em escalas e arpejos, e à repetição de padrões rítmicos. Apesar desses componentes terem sido utilizados anteriormente por Haydn e Mozart, e com essa finalidade, Beethoven os emprega de maneira inesperadamente obstinada, conferindo-lhes grande originalidade. Esses elementos adquirem tanta força em sua obra, que chegam a assumir status de material temático principal, como ocorre, por exemplo, com o famoso motivo inicial da Quinta Sinfonia, op. 67 (1808). O ritmo das primeiras quatro notas é incansavelmente repetido, tornando-se o elemento gerador de todo o primeiro movimento e sendo novamente mencionado nos movimentos seguintes. Essa insistência gera uma tensão que ocasionou, já na época de sua composição, a ideia de que as quatro famosas notas representariam as batidas do Destino. Desde sua composição, a Quinta Sinfonia é considerada uma obra absolutamente surpreendente.

Embora Haydn e Mozart já moldassem seus temas musicais de forma a realçar o caráter dos movimentos, Beethoven exacerba o contraste, utilizando uma amplitude sonora muito maior - ninguém antes havia feito uma orquestra soar tão forte ou tão suave, por tanto tempo, e explorado com tanta insistência a oposição entre esses extremos; emprega ainda os diferentes instrumentos de forma criativa, valorizando o colorido timbrístico. Esses recursos contribuíram para aumentar a gama de emoções retratadas. Com Beethoven, os andamentos rápidos tenderam a se tornar mais grandiosos ou dramáticos; os lentos, mais 
densos e expressivos; os minuetos e scherzi, tão típicos da escrita delicada de Haydn, mais turbulentos ou mesmo grotescos.

É interessante notar que o processo de composição das sinfonias de Beethoven não é diverso, em si, daquele proposto por Haydn. ${ }^{12}$ Entretanto, a amplificação máxima dos mesmos procedimentos é responsável por gerar obras de dimensões e amplitude muito maiores. Vale lembrar que só o movimento inicial da Terceira Sinfonia, "Eroica", op. 55, é tão longo quanto uma sinfonia inteira de Haydn ou Mozart. Na época, este detalhe não passou despercebido, tendo sido tão admirado quanto criticado.

Nessa Terceira Sinfonia, a escrita mais galante das duas anteriores dá lugar a um estilo impetuoso e violento. Inicialmente dedicada a Napoleão Bonaparte, sobrevive, no frontispício, uma violenta rasura, e a substituição do tributo inicial pelo texto "Sinfonia Eroica, composta para celebrar a memória de um grande homem". As prescrições de Koch a respeito do caráter brilhante e fogoso da sinfonia tomam rumos radicais: o afeto grandioso de "Eroica" contrasta com a obstinação da Quinta Sinfonia (op. 67) e com o lirismo da Sexta Sinfonia, "Pastoral" (op. 68).

O núcleo principal das sinfonias de Beethoven abrange um período de doze anos, compreendido entre 1800 (estreia da Primeira, op. 21) e 1812 (composição da Oitava, op. 93). Nesse contexto, a Nona e última, op. 125, finalizada em 1824, constitui-se num evento isolado e muito mais tardio. Nessa, o retardamento do ritmo harmônico é tal que a peça tem uma duração totalmente inédita para os padrões da época, ultrapassando uma hora de música. Seus movimentos são tão extensos que é difícil entendê-la com um todo.

A lógica que rege a progressão de acordes, que já é de difícil compreensão nas sinfonias anteriores, torna-se ainda mais obscura, o que contribui para manter o interesse dos ouvintes, pois exige uma escuta mais atenta. $\mathrm{O}$ aumento de extensão de cada movimento acaba por engendrar alterações na forma. $\mathrm{O}$ modelo previsto por Haydn, com movimentos divididos em duas partes que se repetem, possibilitava que o ouvinte engenhoso compreendesse claramente a direção da harmonia. Esse modelo é parcialmente adotado por Beethoven nas oito sinfonias anteriores, que omitem a repetição da segunda parte. Na Nona, essas repetições internas são totalmente eliminadas em prol de um desenvolvimento constante ao longo dos movimentos. O mesmo ocorre em alguns dos últimos quartetos e sonatas para piano.

Na Nona Sinfonia, Beethoven amplia o colorido orquestral, não apenas incluindo instrumentos de sopro e de percussão diversos, como o contrafagote, triângulo, pratos, bombo etc., mas principalmente pela inclusão de um coro e de solistas vocais, o que the conferiu o epíteto Sinfonia "Coral". Nessa peça, as vozes humanas são equilibradas com os demais instrumentos, formato esse posteriormente utilizado por compositores como Berlioz, Mendelssohn, Liszt e Mahler. O texto escolhido para a Sinfonia "Coral" foi um trecho da ode An die 


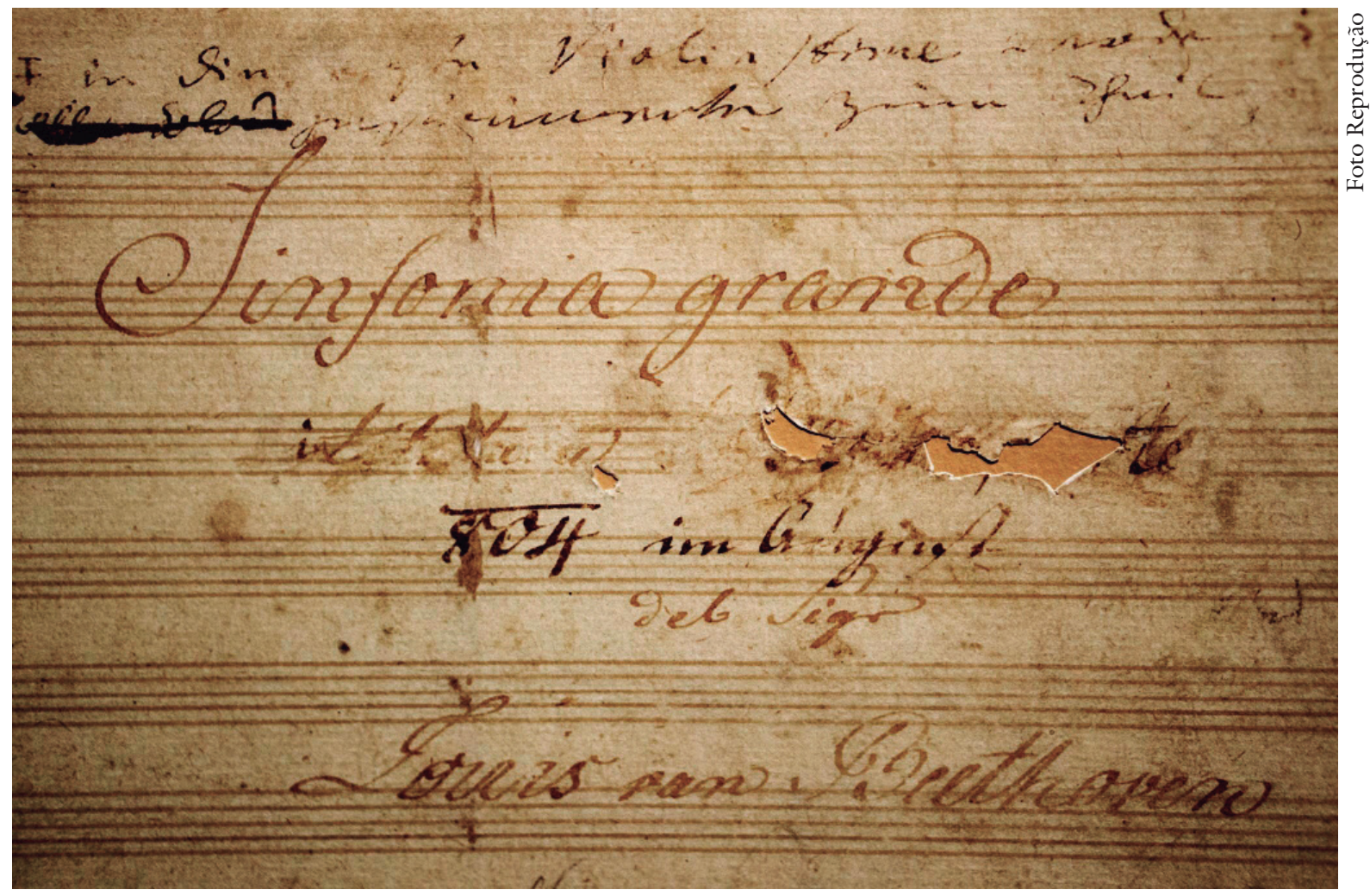

Folha de rosto do manuscrito da Eroica, onde podemos ver o rasgo no papel, resultado do ato de Beethoven ao riscar o nome de Napoleão Bonaparte.

Freude ["À alegria"], de Schiller, cantado no último movimento. Este tornou-se, em 1972, o Hino da Comunidade Europeia. A posição icônica que essa obra ocupa desde sua estreia, refletiu-se, ainda, no valor atingido pelo leilão de seus manuscritos originais, em 2003: 3,3 milhões de dólares.

A lógica composicional extremamente amplificada praticada por Beethoven na Nona Sinfonia tornou-se tão complexa que não foi absorvida por seus contemporâneos e pósteros, que frequentemente tomaram sinfonias anteriores, em especial a Sétima, como modelos para suas próprias composições.

\section{Considerações finais}

Ao discorrer sobre a música instrumental de Beethoven, destacamos determinados procedimentos que a caracterizam. Alguns constituem-se em desenvolvimentos em relação a seus modelos, Mozart e, sobretudo, Haydn. O ritmo harmônico com áreas bem definidas praticado por Haydn é alargado, e, especialmente nos seus últimos anos, a relação entre as harmonias se torna cada vez mais complexa. O uso de padrões rítmicos repetidos que geram desenvolvimentos melódicos também é uma técnica herdada de Haydn. Entretanto, Beethoven os utiliza com uma insistência que confere grande energia e originalidade a suas obras. Estas soluções, embora surpreendentes, consistem em empregos engenhosos dos elementos já fornecidos pelo autor de $A$ Criação. 
As modificações que os instrumentos musicais sofreram nessa época também acompanharam e ajudaram a fomentar as transformações estéticas. $\mathrm{O}$ aumento da gama das intensidades, com fortíssimos e pianíssimos inusitados - e o contraste exacerbado entre eles -, assim como novas possibilidades sonoras, são alguns dos exemplos. Nesse ponto, a habilidade de Beethoven como pianista certamente colaborou na descoberta de muitos dos aspectos inovadores de sua música, sobretudo por que esse era o domínio em que se sentia mais livre para ousar.

A distribuição mais igualitária do material temático entre os integrantes de suas obras camerísticos, também é uma inovação de Beethoven que serve de premissa até os dias de hoje.

Dessa maneira, seja no uso ampliado de técnicas herdadas de Haydn, matizadas pela sensibilidade de Mozart, seja por incorporar procedimentos novos que não faziam parte do léxico de seus antecessores, Beethoven consegue expressar uma gama de emoções muito mais ampla do que seus mestres.

Nesse contexto, a comparação entre a graça de Haydn e a energia de Beethoven acabou por pesar negativamente para o músico mais velho, cuja posição foi, em um julgamento rápido e pouco aprofundado, limitada à de "precursor". No entanto, é difícil compreender totalmente a grandeza da música de Beethoven se não partirmos da comparação com Haydn e da noção de sua importância.

É curioso observar que Beethoven não chegou a romper com os protocolos de decoro setecentista: suas sonatas para piano e sua música de câmera seguiram sendo um fértil campo para experimentação e, ainda que também tenham sido apresentadas em teatros públicos, mantiveram a escrita complexa, mais adequada a um grupo seleto de ouvintes iniciados, como aquele frequentador das câmeras aristocráticas. A sinfonia e o concerto seguiram cumprindo sua função comovente, seja pela expressão de grandiosidade prevista na primeira, ou pela exibição de virtuosismo proposta no segundo.

A criatividade, o domínio técnico composicional e a capacidade de comunicação e inovação de Beethoven coincidiram extraordinariamente com o momento histórico, em que foram protagonizadas profundas mudanças estéticas. Isso lhe permitiu alcançar uma posição fulcral no desenvolvimento da música ocidental.

Suas ideias sobre estruturas formais, relações de tonalidade, dinâmica, tempo, textura e intenções dramáticas são a base dessas transformações que floresceram com o romantismo do século XIX.

Em 1822, cinco anos antes de sua morte, em conversa com o editor do diário musical de Leipzig, Beethoven externa seu sentimento de total isolamento da vida musical de Viena, tanto do ponto de vista pessoal quanto profissional. $\mathrm{O}$ fato de ter sido universalmente considerado o maior compositor vivo, não diminuiu essa crescente sensação de não pertencimento (Rosen, 1997, p.379). Uma evidência do respeito público granjeado por Beethoven foi seu funeral, um 
acontecimento grandioso que testemunhou essa fama excepcional. Uma multidão estimada entre dez e vinte mil pessoas acompanhou o féretro até o cemitério de Währing (Solomon, 1987, p.390). Em 1888, seus restos mortais foram transferidos para o Cemitério Central de Viena, onde ainda hoje repousam.

Paradoxalmente, sua obra, embora admirada, respeitada e amada, dificilmente foi uma força vital para seus contemporâneos mais jovens, exceto Schubert, e para a geração que a ele se seguiu. Na realidade, o poder de seu legado ofuscou os compositores da primeira metade do século XIX. Esses estavam cientes da impossibilidade de expandir o modelo fornecido por Beethoven. Viram-se, por isso, forçados a trilhar caminhos compositivos diversos, afastando-se definitivamente dos processos haydnianos. Pode-se dizer que quase tudo o que é mais interessante na próxima geração é uma reação contra Beethoven, ou uma tentativa de ignorá-lo, representando um desvio para novas direções. A produ-

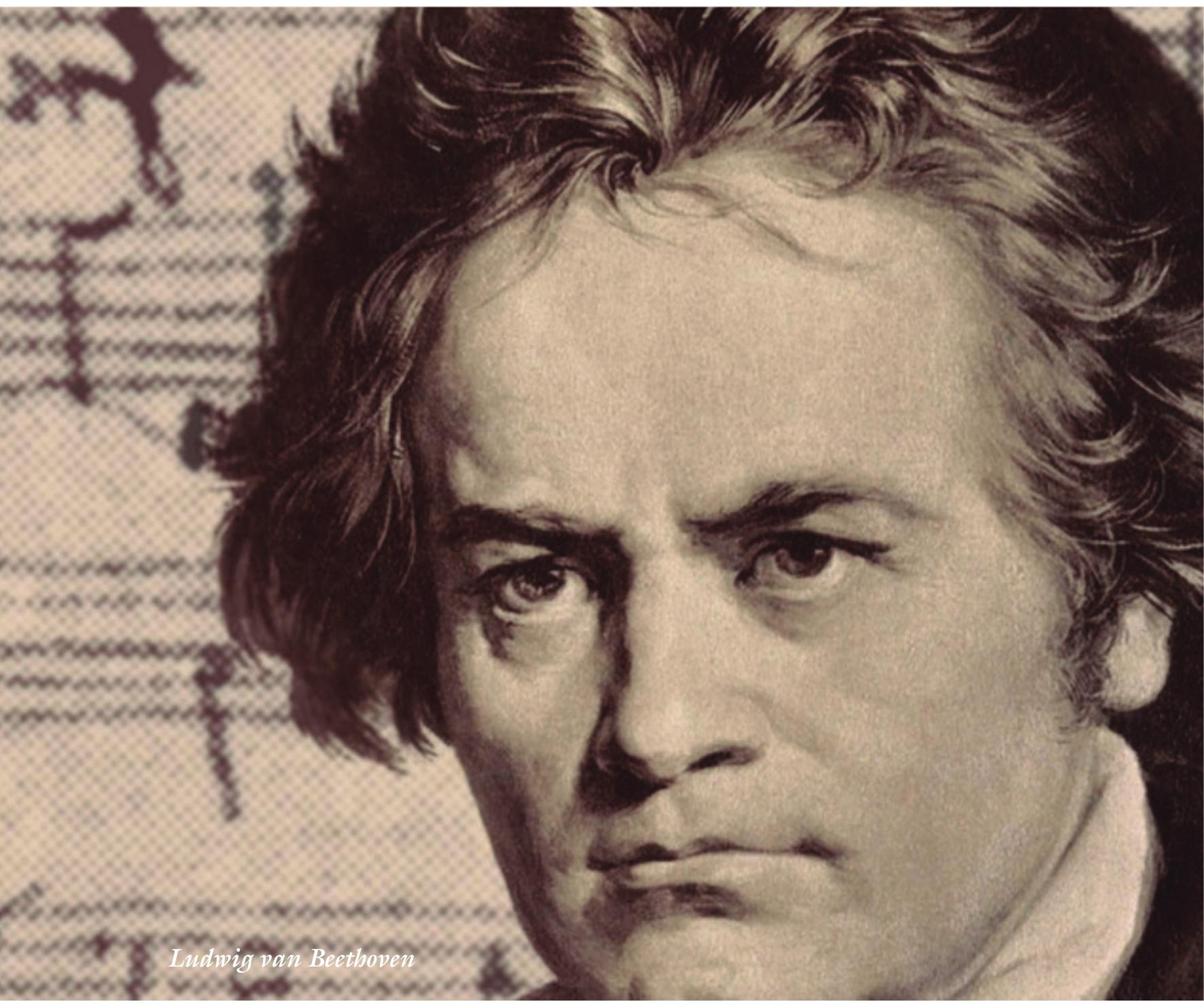


ção que segue seu modelo é, em geral, mais fraca e lhe presta uma homenagem sincera, porém vazia (Rosen, 1997, p.379).

Tentar explicar em palavras o poder de comunicação da música de Beethoven talvez seja impossível. Por que uma simples progressão harmônica de dominante para tônica em Beethoven soa mais expressiva do que aquela realizada por seus contemporâneos? Por que um movimento lento de Beethoven pode nos remeter à humanidade que nos une a todos com tanta força, enquanto movimentos lentos de outros são meramente comoventes? Por que as sonoridades propostas pelo autor da Nona evocam a euforia da esperança da vitória do homem sobre o destino, enquanto as de outros apenas sugerem entusiasmo e eloquência? Em grande parte, essas perguntas resistem a respostas objetivas.

Stewart Gordon (2017, p.51-2), ao mencionar o desafio que consiste em procurar traduzir em palavras a força expressiva da música de Beethoven, aponta que a mesma dificuldade ocorre na tentativa de definir crenças espirituais: muitas vezes, aqueles que acreditam em um poder superior afirmam que passaram por uma espécie de revelação mística, impossível de ser verbalizada. Acrescentam, ainda, que somente a experiência em si permitiria compreender e acreditar; exortam os demais a vivenciar processos semelhantes e estão convencidos de que aqueles que buscam serão recompensados e se juntarão à uma irmandade de iluminados.

Gerações de músicos, estudiosos e ouvintes testemunham a maravilhosa capacidade da música de Beethoven de comover, elevar e iluminar. Ao tentar traduzir em palavras ou definir esse fenômeno, foram ricamente recompensados nessa busca do indizível e adentraram a legião de seus adoradores.

\section{Notas}

l Como Cherubini (1760-1842), Viotti (1755-1824), Clementi (1752-1832), Dussek (1760-1812), Grétry (1741-1813), Méhul (1763-1817), Pleyel (1757-1831), Salieri (1750-1825), Steibelt (1765-1823), Sterkel (1750-1817), Hummel (1778-1837) etc.

2 "(Mozart) baute auf Haydns lieblich phantastisches Gartenhaus seinen Pallast. Be[e] thoven hatte sich früh schon in diesem Pallast eingewohnt, und so blieb ihm nur, um seine eigene Natur auch in eignen Formen auszudrücken, der kühne, trotzige Thurmbau, auf den so leicht keiner weiter etwas setzen soll, obne den Hals zu brechen". (Reichardt, 1810, v.1, p.231-2). Esta passagem também foi citada no jornal vienense Allgemeine Musikalische Zeitung (v.12, 7 fev. 1810, p.289). Todas as traduções, exceto quando diversamente especificado, são nossas.

3 A discussão destas circunstâncias musicais é descrita, por exemplo, em Der vollkommene Capellmeister ["O mestre-de-capela perfeito", 1739], de Johann Mattheson (1681-1767), obra presente nas bibliotecas de Haydn e Beethoven.

4 "Die Instrumentalmusik hat in keiner Form bequemere Gelegenheit, ibr Vermögen, ohne Wörter Empfindungen zu schildern, an den Tag zu legen, als die Sonate”.

5 A prática dos estilos concertati remete em especial à produção que envolvia compositores ligados à Basílica de San Marco, em Veneza, particularmente Giovanni Gabrieli (1557-1612). 
6 A opinião de Schultz se encontra na Allgemeine Theorie der schönen Kunste, editada por Johann Georg Sulzer, 1774. Koch (2001, col.353-4), por sua vez, afirma: "Não nos espanta que homens de gosto refinado, como Sulzer, levados pelas besteiras que se dizem acerca do concerto, rebaixem-no a um mero exercício para compositores e intérpretes, e nada além de pura diversão auditiva. Embora esta descrição seja verdadeira, não se conclui daí que a forma do concerto é menos importante que a forma de outras peças adequadas à representação das paixões" ["Kein wunder daher, wenn Männer von feinem Geschmack, durch den Unfug verleitet, der mit dem Concerte getrieben wird, es so wie Sulzer zu einer blossen Uebung für Setzer und Spieler, und zu einer auf weiter nichts abzielenden Ergötzung des Obres, herabsetzen. So wahr diese Beschreibung ist, wenn ein Concert wie vorhin gerügten Febler hat, so wenig fogt daraus, dass die Form des Concertes weniger, alis die Form eines anderen Tonstückes, zu einem leidenschaftlichen Tongemälde geeignet sey"].

7 WoO (Werk obne Opuszahl, ou "obra sem número de opus") é a designação dada às obras que não foram publicadas por Beethoven ou que sobreviveram apenas de forma fragmentária, não recebendo, portanto, um número de opus.

8 Esse efeito de mistura das harmonias é mais evidente, e eficiente, em um instrumento histórico.

9 Cf. Disponível em: <https://en.wikipedia.org/wiki/Piano_Sonata_No._17_(Beethoven) $>$.

10 Cf. Disponível em: <https://www.henle.de/blog/en/2017/06/05/4449/>.

11 Como exemplo podemos citar o fato de cordas e sopros poderem sustentar uma nota por meio do arco e do fôlego, respectivamente, enquanto, no piano, instrumento de cordas percutidas, os sons invariavelmente decrescem após a emissão.

12 A propósito, a influência haydniana é clara nas Sinfonias n.1, op. 21 (1800) e n.2, op. 36 (1802): as duas empregam o elemento surpresa no contexto de uma escrita graciosa, ingredientes que caracterizam a escrita do mestre.

\section{Referências}

BONDS, M. E. The Beethoven Syndrome. Hearing music as autobirography. New York: Oxford University Press, 2020.

CHIANTORE, L. Beethoven al piano: Improvisación, composición e investigación sonora en sus ejercicios técnicos. Barcelona: Nortesur, 2010.

COOPER, B. The Creation of Beethoven's 35 Piano Sonatas. Abingdon, Oxon: Routledge, 2017 (Ashgate Historical Keyboard Series).

CROCKER, R. A History of Musical Style. New York: Dover, 1986.

DAHLHAUS, C. Ludwig van Beethoven und seine Zeit. Laaber: Laaber Verlag, 1987.

GINGERICH, J. Ignaz Schuppanzigh and Beethoven's Late Quartets. The Musical Quarterly, v.93, n.3/4, p.450-513, 2010.

GORDON, S. Beethoven's 32 Piano Sonatas. A Handbook for Performers. New York: Oxford University Press, 2017.

KINDERMANN, W. The piano music: concertos, sonatas, variations, smallforms In: 
STANLEY, G. (Ed.) The Cambridge Companion to Beethoven. Cambridge: Cambridge University Press, 2000.

Press, 2006.

The String Quartets of Beethoven. Urbana and Chicago: University of Illinois

KOCH, H. C. Musikalisches Lexikon. Kassel [Frankfurt am Main]: Bärenreiter [Hermann der Jünger], 2001 [1802].

KUNZE, S. (Ed.) Ludwig van Beethoven: Die Werke im Spiegel seiner Zeit. Laaber: Laaber Verlag, 1987.

LOCKWOOD, L. Beethoven. The music and the life. New York: Norton, 2003.

MATTHESON, J. M. Der Vollkommene Capellmeister. Kassel [Hamburg]: Bärenreiter [Christian Herold], 1991 [1739].

PIANO Sonata n.17 (B). Disponível em: <https://en.wikipedia.org/wiki/Piano_Sonata_No._17_(Beethoven)>. Acesso em: 20 set. 2020.

RATNER, L. Classic Music. Expression, form and style. New York: Schirmer, 1980.

REICHARDT, J. F. Vertraute Briefe, geschrieben auf einer Reise nach Wien und den oesterreichischen Staaten zu Ende des Jahres 1808 und zu Anfang 1809. Amsterdam: Kunst- und Industrie- Comptoir, 1810 (2v.). Disponível em: <https://reader.digitale-sammlungen.de/de/fsl/object/display/bsbl0623219_00005.html>. Acesso em: 11 set. 2020.

ROSEN, C. The Classical Style: Haydn, Mozart, Beethoven. New York: W. W. Norton \& Company, 1997.

SOLOMON, M. Beethoven, trad. Álvaro Cabral. Rio de Janeiro: Jorge Zahar Editor, 1987.

SULZE, A. P. Allgemeine Theorie der Schönen Künste. Leipzig: Weidmann, 1771-1774 (2v.). Disponível em: <https://books.google.com.br/books?id=8wYFAAAAYAAJ\&p rintsec $=$ frontcover $\& h \mathrm{l}=\mathrm{de} \&$ source $=\mathrm{gbs} \_g e \_s u m m a r y \_r \& c a d=0 \# \mathrm{v}=$ onepage $\& \mathrm{q}=$ sonate $\& f=$ false $>$. Acesso em: 21 set. 2020.

STANLEY, G. (Ed.) The Cambridge Companion to Beethoven. Cambridge: Cambridge University Press, 2008 [2001].

THE AUTHENTIC Epithets. Disponível em: <https://www.henle.de/blog/ en $/ 2017 / 06 / 05 / 4449 />$. Acesso em: 18 set. 2020.

TÜRK, D. G. Clavierschule oder Anweisung zum Clavierspielen führ Lehrer und Lernende. Kassel [Leipzig und Halle]: Bärenreiter [Schwickert], 1997 [1789].

RESUMO - Ao celebrar os 250 anos do nascimento de Ludwig van Beethoven (17701827), constata-se que sua obra preserva, intacto, o poder de fascinar seus ouvintes. Sua competência única coincidiu extraordinariamente com um momento histórico em que foram protagonizadas profundas mudanças estéticas, o que lhe permitiu alcançar uma posição fulcral no desenvolvimento da música ocidental. O conde Waldstein, um de seus protetores, declarou em 1792: “você receberá o espírito de Mozart pelas mãos de Haydn" (apud Rosen, 1997, p.19). Beethoven, de fato, empregou os processos 
herdados de seus mestres, incorporando a eles procedimentos novos e criativos que permitiram à sua música expressar uma gama de emoções muito mais ampla. O presente artigo assinala alguns aspectos musicais que colaboram para a compreensão da rara dimensão alcançada pelo compositor, abordando sua produção no contexto da música instrumental a partir do final do século XVIII.

PALAVRAS-CHAVE: Beethoven, Música instrumental, Decoro, Gênero musical, Estilo musical.

ABSTRACT - In celebrating the 250th anniversary of Ludwig van Beethoven (17701827), his works have retained, unchanged, the power to fascinate its listeners. Beethoven's unique competence coincided extraordinarily with a historic moment in which profound aesthetic changes took place, allowing him to reach a pivotal position in the development of Western music. Count Waldstein, one of his protectors, declared in 1792, "You will receive the spirit of Mozart from the hands of Haydn" (apud Rosen, 1997, p.19). Thus, Beethoven used processes he inherited from his masters, incorporating new and creative procedures that allowed his music to express a much wider range of emotions. This article points out some musical aspects that help us to understand the rare dimension he attained by examining his production within the context of instrumental music of the late $18^{\text {th }}$ century.

KEYWORDs: Beethoven, Instrumental music, Decorum, Musical genre, Musical style.

Eduardo Monteiro é pianista, diretor da Escola de Comunicações e Artes da USP (2017-21), onde é professor de piano do Departamento de Música.

@ - ehsmonteiro@hotmail.com / https://orcid.org/0000-0002-0084-871X.

Mônica Lucas é musicista e professora do Departamento de Música da Escola de Comunicações e Artes da USP. É diretora artística do Conjunto de Música Antiga da USP. @-monicalucas@live.com / https://orcid.org/0000-0001-8183-0070.

Recebido em $1^{\circ} .10 .2020$ e aceito em 5.10.2020.

I, II Escola de Comunicações e Artes, Universidade de São Paulo, São Paulo, Brasil. 


\section{Anexo}

Ludwig van Beethoven: Sonata n. 23, em fá menor, op. 57, "Appassionata”

$$
\begin{gathered}
\text { Allegro assai (Faixa 1) } \\
\text { Andante con moto (Faixa 2) } \\
\text { Allegro ma non tropo - Presto (Faixa 3) }
\end{gathered}
$$

Faixas 1 a 3 do CD Eduardo Monteiro piano, gravado no Teatro Cultura Artística de São Paulo em setembro de 2005, por ocasião do recital comemorativo aos 10 anos da Revista Concerto.

A Sonata n. 23, em fá menor, op. 57, Appassionata, se inicia de forma suave e misteriosa. Os contrastes extremos de intensidade que caracterizam o primeiro movimento, Allegro assai, exacerbam o drama que dele transborda, e levam a compreender o porquê do epíteto da obra. O segundo movimento, Andante con moto, está incrustrado entre os monumentais movimentos extremos. Apesar da profunda poesia, sua beleza, às vezes, pode passar despercebida em uma primeira escuta. Ele se inicia na região grave, com um tema em forma de coral, ao qual se seguem três variações em que a melodia aparece em uma região cada vez mais aguda e as notas do acompanhamento se tornam sempre mais rápidas. $\mathrm{O}$ trecho inicial é retomado ao fim, quando uma harmonia enigmática frustra uma conclusão pacífica e conduz, através de uma série de treze acordes repetidos em fortíssimo, ao terceiro movimento, Allegro ma non troppo-Presto, que retoma o caráter enérgico do início da obra. É necessário grande vigor físico para manter a agitação incessante, quase caótica, com notas extremamente rápidas, que soam mesmo ameaçadoras. A coda, que se inicia com um novo elemento, em acordes, deve ser executada ainda mais rapidamente, e conclui a obra com arpejos descendentes que parecem querer colapsar sobre si mesmos. 